\title{
First record of thrips species and their damage to carrot in Alto Paranaíba
}

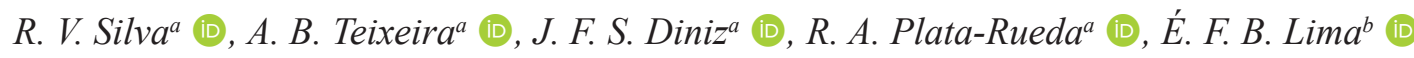 \\ and F. L. Fernandes ${ }^{a *}$ (D)
}

${ }^{a}$ Laboratório de Manejo Integrado de Pragas, Instituto de Ciências Agrárias - IAP, Universidade Federal de Viçosa - UFV, Campus Rio Paranaíba, MG 230, Km 08, CEP 38810-000, Rio Paranaíba, MG, Brasil

${ }^{\text {b}}$ Departamento de Biologia, Centro de Ciências da Natureza, Universidade Federal do Piauí - UFPI, Campus Amílcar Ferreira Sobral, BR 343, Km 3.5, CEP 64808-605, Floriano, PI, Brasil

*e-mail: flaviofernandes@ufv.br

Received: July 4, 2018 - Accepted: September 18, 2018 - Distributed: February 28, 2020

(With 1 figure)

Thrips are phytophagous insects that feed on several plants, mainly grape (Vitis vinifera), onion (Allium cepa), cowpea (Vigna unguiculata), tomato (Solanum lycopersicon), cotton (Gossypuim hirsutun), and peanut (Arachis hypogaea) (Gonçalves, 2006; Botton et al., 2007; Freddi et al., 2007; Fontes et al., 2011; Macharia et al., 2015; Schneweis et al., 2016). These insects cause direct and indirect damage to commercial crops. The direct damages are due to scraping of the stems, leaves, flowers, and fruits and, because of the suction of the sap, the attacked part is left silvered and coiled. The indirect damage is caused by the transmission of viruses, such as the Tospovirus, losses in production, quality and commercial value (Monteiro et al., 2001).

Thrips (Insecta: Thysanoptera) cause financial losses in vegetables. How Neohydatothrips signifer (Priesner, 1932) (Thysanoptera: Thripidae) causes economic damage when its population density reaches 13 thrips per meristem of onion (Allium cepa) (Santos et al., 2012). Caliothrips phaseoli (Hood, 1912) (Thysanoptera: Thripidae), reduces the productivity of common bean (Phaseolus vulgaris) when its population density exceeds 100 thrips per meter or tree thrips per flowers (Quintela, 2001). Thrips tabaci (Linderman, 1888) (Thysanoptera: Thripidae) in populations greater, than 10 thrips per plant, may reduce the yield of onion (Gonçalves, 1998).

Thrips can colonize several micro habitats: flowers, branches and leaves (Pinent et al., 2006). We have observed thrips feeding on the carrot crop (Daucus carota), but we do not know what species occurs. Quantification the number of individuals, species identification, and describe the damages can help in the management and prediction of future problems to this culture. Thus, we aimed to report the occurrence of thrips species feeding on carrot in Brazil.

The samples were collected in three fields of carrot (D. carota) in the cultivars Verano and Erica, in the region of Alto Paranaíba, Minas Gerais, Brazil, at 19¹3'96" S, $46^{\circ} 13^{\prime} 28^{\prime \prime} \mathrm{W}$ and altitude of $1,138 \mathrm{~m}$ from March to July 2016. The region has subtropical climate, with annual average precipitation of $1,533 \mathrm{~mm}$ per year and temperature of $20.4{ }^{\circ} \mathrm{C}$, soil type is red-yellow latosol and lowland terrain relief in a Brazilian Cerrado biome. Before sowing, a plowing and two harrowings were carried out. After that, sowing took place in March/2016, with a pneumatic machine (mechanical seeding), which has the advantage of simultaneously opening the grooves, distributing the seeds, and covering the grooves with great efficiency. The seeds were spaced by $12 \mathrm{~cm}$ between rows (total of 5 rows per plot) and about $3 \mathrm{~kg}$ of seeds/hectare were spent in an area of 15.2 ha.

We had tree carrot fields, two of Verano cultivar and one of Erica cultivar. We evaluated 162 plants in field one (Verano), 96 in field two (Erica), and 384 in field three (Verano). Thrips densities evaluations began 20 days after the emergence of the seedlings. In each field, 16 equidistant $(30 \mathrm{~m})$ points were settled, in order to cover the entire area. Three plants in each point were observed by the white plastic tray tapping technique (Moura et al., 2003). The samples of thrips were collected and kept in 70\% alcohol and sent to Dr. Élison Fabrício Bezerra Lima of the Universidade Federal do Piauí - UFPI, Campus Amílcar Ferreira Sobral.

The number of thrips per plastic tray tapping sampled was $6.94 \pm 2.80$ to field one (Verano), $3.84 \pm 0.31$ to field two (Erica), and $3.68 \pm 0.31$ in field three (Verano). Among the thrips sampled, we collected in all the areas 28 females and seven males of Caliothrips phaseoli (Hood, 1912) (Thysanoptera; Thripidae) (Figure 1d), four females of Thrips tabaci (Linderman, 1888) (Thysanoptera; Thripidae) (Figure 1e), and three females of Frankliniella schultzei (Trybom, 1910) (Thysanoptera: Thripidae). These species have been reported in carrots and are found to cause economic damage to bean, tomato, and potato crops (Monteiro et al., 2001; Dequech et al., 2011; Zanuncio-Junior et al., 2016). However, this study is the first to report T. tabaci, F. schultzei, and C. phaseoli in this culture for the Alto Paranaíba region. This information is relevant for the integrated management of pest species, since its identification is a fundamental step for the control methods. Although no proportion can be established among the species present in the crops, more research is needed to monitor thrips and to determine their role as pests in carrot crops (D. carota) in Brazil.

Among the observed symptoms caused by the thrips complex in the leaflets and the rachis of D. carota leaves, 


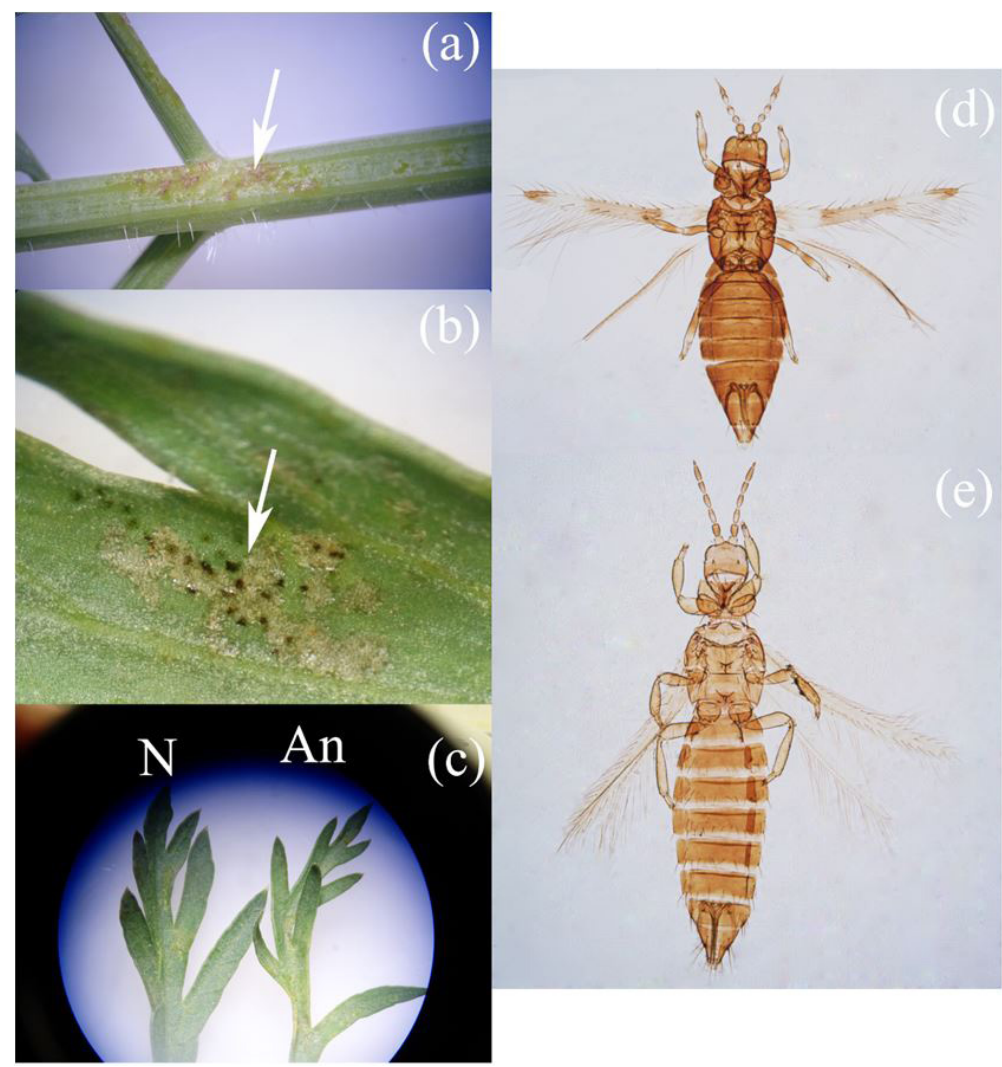

Figure 1. Damage by thrips in the rachis (a); faeces and scraping in the leaflet (b); leaflet shrivelling (c); Caliothrips phaseoli (d) and Thrips tabaci (e) from carrot crop, Minas Gerais, Brazil from March to July 2016. AN= abnormal, N= normal, white arrow points to the damage site.

where they caused necrotic patches throughout the upper third of the leaf rachis (Figure 1a), as observed in watermelon crops when the attacked parts present a burnt or silvery appearance and dark spots (Michereff Filho et al., 2010), during the suction of the intracellular content by the thrips, the cells, while extracted, give to the plant tissue silver spots and later brownish spots due to the extravasated cells and accompanied by black spots that are the faeces deposited by thrips (Nondillo et al., 2010) (Figure 1b), and foliar shrivelling (Figure 1c) similar to the most characteristic symptoms of tomato "vira-cabeça" disease, transmitted by viruses of the Tospovirus genus disseminated by thrips that cause foliar distortion necrosis in young leaves and death of the stems (Albuquerque et al., 2012).

To report the occurrence of the thrips complex in the carrot culture is a way of anticipating bioecology studies, control methods, and other strategies of population density reduction, mainly because these species already reduce the productivity. There are several examples of insects that started to attack crops and became important pests in the future.

From this study, we concluded that there are different species of thrips in both Verano and Erica cultivars and that they cause damages to the crop.

\section{References}

ALBUQUERQUE, L.C., VARSANI, A., FERNANDES, F.R., PINHEIRO, B., MARTIN, D.P., FERREIRA, P.T.O., LEMOS, T.O. and INOUE-NAGATA, A.K., 2012. Further characterization of tomato-infecting begomoviruses in Brazil. Archives of Virology, vol. 157 , no. 4 , pp. 747-752. http://dx.doi.org/10.1007/s00705011-1213-7. PMid:22218964.

BOTTON, M., NONDILLO, A., ZART, M., PINENT, S. and GENTA, W. 2007 [viewed 4 June 2018]. Avaliação de inseticida para controle de Frankliniella rodeos (Moulton, 1933) (Thysanoptera: Thripidae) em uva de mesa no Brasil. Boletín Sanidade Vegetal [online], vol. 33, no. 4, pp. 575-580. Available from: http:// www.mapa.es/ministerio/pags/biblioteca/revistas/pdf_Plagas/ BSVP_33_04_575_580.pdf

DEQUECH, S.T.B., RIBEIRO, L.P., SAUSEN, C.D., MARTINS, J.D. and EGEWART, R. 2011 [viewed 4 June 2018]. Atividade inseticida de extratos de meliáceas sobre Caliothrips phaseoli HOOD, 1912 (Thysanoptera: Thripidae) em cultivos em estufa plástica. Revista da Faculdade de Zootecnia Veterinária e Agronomia [online], vol. 18, no. 1, pp. 68-77. Available from: http:// revistaseletronicas.pucrs.br/ojs/index.php/fzva/article/view/8049

FONTES, L.S., PINENT, S.M.J., LIMA, É.F.B. and SUCUPIRA, I.G., 2011. First register of occurrence of Frankliniella schultzei (Trybom, 1910) (Thysanoptera: Thripidae) in Cowpea (Vigna unguiculata (L.) Walp.) in the state of Piauí, Brazil. Brazilian Journal 
of Biology $=$ Revista Brasileira de Biologia, vol. 71, no. 4, pp. 1023-1024. http://dx.doi.org/10.1590/S1519-69842011000500023.

FREDDI, O.S., CAMPOS, A.R., LEONEL, C.L., FREDDI, T.S. and BARBOSA, G.F., 2007. Período de suscetibilidade do amendoinzeiro cv. Tégua ao tripes do prateamento e seu reflexo na produtividade. Acta Scientiarum. Agronomy, vol. 29, no. 2, pp. 277-282. http://dx.doi.org/10.4025/actasciagron.v29i2.271.

GONÇALVES, P.A., 1998. Determinação do nível de dano econômico de tripes em cebola. Horticultura Brasileira, vol. 16 , no. 2, pp. 128-131. http://dx.doi.org/10.1590/S010205361998160000200007.

GONÇALVES, P.A.S. 2006. Manejo ecológico das principais pragas da cebola. In: J.A. WORDELL FILHO, P.A.S. GONÇALVES, E. ROWE and J.F. DEBARBA, eds. Manejo fitossanitário na cultura da cebola. Florianópolis: Epagri, pp. 168-189.

MACHARIA, I., BACKHOUSE, D., SKILTON, R., ATEKA, E., WU, S.B., NJAHIRA, M., MAINA, S. and HARVEY, J., 2015. Diversity of thrips species and vectors of tomato spotted wilt virus in tomato production systems in Kenya. Journal of Economic Entomology, vol. 108, no. 1, pp. 20-28. http://dx.doi. org/10.1093/jee/tou010. PMid:26470099.

MICHEREFF FILHO, M., GUIMARÃES, J.A. and LIZ, R.S., 2010 [viewed 4 June 2018]. Pragas da melancia e seu controle [online]. Brasília: Embrapa Hortaliças. Circular Técnica, no. 92. Available from: http://ainfo.cnptia.embrapa.br/digital/bitstream/ item/128820/1/ct-92.pdf

MONTEIRO, R.C., MOUND, L.A. and ZUCCHI, R.A., 2001. Espécies de Frankliniella (Thysanoptera: Thripidae) de importância agrícola no Brasil. Neotropical Entomology, vol. 30, no. 1, pp. 65-72. http://dx.doi.org/10.1590/S1519-566X2001000100011.

MOURA, M.F., PICANÇO, M.C., SILVA, E.M., GUEDES, R.N.C. and PEREIRA, J.L., 2003. Plano de amostragem do biótipo B de Bemisia tabaci na cultura do pepino. Pesquisa Agropecuária Brasileira, vol. 38, no. 12, pp. 1357-1363. http:// dx.doi.org/10.1590/S0100-204X2003001200001.
NONDILlO, A., REDAELLI, L.R., PINENT, S.M.J. and BOTTON, M., 2010. Caracterização das injúrias causadas por Frankliniella occidentalis no morangueiro. Ciência Rural, vol. 40, no. 4, pp. 820-826. http://dx.doi.org/10.1590/S010384782010005000050

PINENT, S.M.J., ROMANOWSKI, H.P., REDAELLI, L.R. and CAVALLERI, A., 2006. Estrutura e composição de espécies de comunidades de Thysanoptera em diferentes micro-hábitats no Parque Estadual de Itapuã, Viamão, RS. Brazilian Journal of Biology $=$ Revista Brasileira de Biologia, vol. 66, no. 3, pp. 765-779. http://dx.doi.org/10.1590/S1519-69842006000500002. PMid:17119824.

QUINTELA, E.D. 2001 [viewed 4 June 2018]. Manejo integrado de pragas do feijoeiro [online]. Santo Antonio de Goiás: Embrapa. Circular Técnica, no. 46. Available from: https://www.infoteca. cnptia.embrapa.br/infoteca/bitstream/doc/192814/1/circ46.pdf

SANTOS, O.A., VARON, E.H.D., GAIGL, A. and FLORIANO, A., 2012 [viewed 4 June 2018]. Economic injury level for Neohydatothrips signifer (Thysanoptera: Thripidae) in passion fruit at the Huila region, Colômbia. Revista Colombiana de Entomologia [online], vol. 38, no. 1, pp. 23-29. Available from: http://www.scielo.org.co/scielo. php?pid=S0120-04882012000100004\&script $=$ sci_arttext\&tlng=pt

SCHNEWEIS, D.J., WHITFIELD, A.E. and ROTENBERG, D., 2016. Thrips developmental stage-specific transcriptome response to tomato spotted wilt virus during the virus infection cycle in Frankliniella occidentalis, the primary vector. Virology, vol. 500, pp. 226-237. http://dx.doi.org/10.1016/j.virol.2016.10.009. PMid:27835811.

ZANUNCIO-JUNIOR, J.S., MARTINS, D.S., FORNAZIER, M.J., VENTURA, J.A., QUEIROZ, R.B., PINET, S.M.J. and ZANUNCIO, J.C., 2016. Thrips species (Thysanoptera: Thipidae) in Brazilian Papaya (Brassicales: Caricaceae) orchards as potencial virus vectors. Florida Entomologist, vol. 99, no. 2, pp. 314-317. https://doi.org/10.1653/024.099.0228. 